\title{
Introduction. Mediating Unity and Diversity through Federalism in Ethiopia
}

\author{
Colin W. Rowe \\ Guest Editor; Research in Political Philosophy Leuven (RIPPLE), Institute of \\ Philosophy, KU Leuven, Leuven, Flemish Brabant, Belgium \\ colin.rowe@kuleuven.be
}

"We, the Nations, Nationalities and Peoples of Ethiopia: Strongly committed, in full and free exercise of our right to self-determination". So opens the Ethiopian Constitution which set Ethiopia on a federal path, aiming to both mediate and accommodate the diversity within its borders. However, federalism is not just about diversity, it is often presented as a compromise between the promotion of freedom through regional or ethnic diversity and the benefits of a large collective through state unity. A stark reminder of this is the armed conflict that flared up at the end of 2020 in Tigray between the TPLF and the Ethiopian government. In federalism's strength we can see its weakness. Its success or failure rests on whether or not it effectively mediates between unity and diversity.

Later in the Ethiopian Constitution's preamble, unity is affirmed as having "through continuous interaction on various levels and forms of life, built up common interest and [has] also contributed to the emergence of a common outlook"; a common outlook that is best served by "by further promoting [Ethiopians'] shared interests".2

This unity is very much what Prime Minister Abiy Ahmed aimed to for with his push towards a more centralized Ethiopia when he came into office in 2018. For some regions and peoples in Ethiopia, however, this centralization represents an attack on their right to self-determination, promised by the opening line of the Constitution.

Ethiopian federalism presented this way may seem to demonstrate an intractable problem with the recent and current armed conflict pointing to federalism's failure there. However, Ethiopia's vast diversity and the great economic

1 Ethiopian Constitution, Preamble.

2 Ibid. 
and other potential benefits of federalism may also lead to the conclusion that federalism is the 'least intractable' political solution for Ethiopia. Indeed, as former Prime Minister, Meles Zenawi, pointed out in respect of adopting federalism in Ethiopia "we have tried all the other major forms of political organisation and the results have been disastrous." ${ }^{3}$ The results of the previous Dergue regime were indeed horrific, so the stakes and the consequences of failure cannot be much higher for Ethiopian federalism. This collection of articles on Ethiopian federalism does not aim to address the current conflicts head on, but rather aims to contribute towards a better understanding and working through of the issues surrounding federalism in Ethiopia.

This special issue was sparked by a joint project on Ethiopian federalism between Mekelle University in Ethiopia and KU Leuven in Belgium which culminated in a workshop in Mekelle in 2018 with the help of Flemish University Development Cooperation funding. Ideas first presented there were developed into several of the contributions to this special issue, with further support from the 'Globalizing Minority Rights' project of the Arctic University of Norway. The goal then, as it is now, is summarized in the project name 'Mediating Unity and Diversity through Federalism in Ethiopia' which is now, more than ever, critical for Ethiopia to avoid further violence. The focus of the project was not only to write on and contribute to literature on Ethiopian federalism and federal theory, but to do so in a way that brings Ethiopia into, and on more level ground, the 'federal family'; to incorporate Ethiopia, Ethiopian theory and concerns.

The focus on Ethiopia is not simply a case study to be solved by western dominated insight, but rather as a unique context that can provide insight as an equal partner in federal theory in a bi-directional exchange.

With that in mind, this special issue is organized into three interlinked themes: what justifies federalism in Ethiopia, how it should be structured, and specifically how to mediate unity and diversity in Ethiopia, in respect of its secession clauses and more generally.

The first three articles focus on justifications for federalism. Meressa Tsehaye Gebrewahd (Mekelle University) and Colin Rowe (KU Leuven) summarize the tensions and conflicts between unity and diversity in Ethiopia and in federal theory as it relates to Ethiopia. The article aims to bring the reader quickly up to date on the core contextual issues surrounding Ethiopia, Ethiopian federalism, contending narratives, and the conceptual distinctions 
in federal theory which can be used to provide clarity when examining and considering this context. ${ }^{4}$

Next, Helder de Schutter (KU Leuven), provides a normative justification for choosing federalism over secession or a unitary government through an argument for federalism as fairness where federalism provides a fairer, and thus a more just context for individuals holding multiple, overlapping identities. ${ }^{5}$

In his article, Colin Rowe (KU Leuven) bridges the 'why' and the 'how' themes by raising the problem of who - which nations, nationalities, peoples or regions - should, normatively speaking, be included in the structure of a federal Ethiopia. That helps determine how the composition of an Ethiopian federal state can be evaluated as just or unjust. To answer this, he produces a normative framework and guiding principles which help in evaluating the normative acceptability of the composition of the Ethiopian federal state. ${ }^{6}$

Moving to the question of how a federal Ethiopia should be structured, François Boucher (KU Leuven) introduces and applies fiscal federalism to Ethiopia. ${ }^{7}$ Fiscal federalism examines the issues surrounding the distribution of financial and other resources and the allocation of fiscal responsibilities (taxing and spending) between different government levels within a federal state.

Seife Hailu Gebreslassie (Mekelle University) rounds off and provides a bridge between the question of how to structure Ethiopian federalism and how to mediate unity and diversity. ${ }^{8}$ In his article, he presents a case for resolving the tensions between self-determination and unity by instituting a 'looser', less central form of federalism in Ethiopia.

Next, Andreas Follesdal (the Arctic University of Norway) and Christophe Van der Beken (Addis Ababa University) present the issues, challenges and opportunities that Ethiopia's secession clauses present. The Ethiopian Constitution provides the right for a group within Ethiopia to secede internally to form a

$4 \quad$ M. Gebrewahd and C. Rowe, 'Mediating unity and diversity in Ethiopia: Insights and challenges for federal theory and practice', 28 The International Journal on Minority and Group Rights (2021), this issue.

5 H. De Schutter, 'Federalism as Fairness in Ethiopia', 28 The International Journal on Minority and Group Rights (2021), this issue.

6 C. Rowe, 'A Question of composition: Constructing a just federal state in Ethiopia and Beyond', 28 The International Journal on Minority and Group Rights (2021), this issue.

7 F. Boucher, 'Fiscal decentralisation in pluri-ethnic states. Equality and autonomy in the Ethiopian Federation', 28 The International Journal on Minority and Group Rights (2021), this issue.

8 S. Gebreslassie, 'Ethiopian federalism: Philosophical and institutional design limitations and a case for loose federalism', 28 The International Journal on Minority and Group Rights (2021), this issue. 
new region within Ethiopia or externally to break away from Ethiopia. Follesdal addresses the practical and theoretical considerations and implications of this clause $^{9}$ while Van der Beken presents the legal issues and opportunities. ${ }^{10}$

Finally, Lovise Aalen (Christian Michelsen Institute), both addresses the secession clauses and gets to the heart of this issue and Ethiopia's federalism, mediating unity and diversity. ${ }^{11}$ In the article, she concludes this special issue by examining the interplay between federalism and dominant party rule in Ethiopia and the Sidama's quest for statehood.

$9 \quad$ A. Follesdal, 'Stability and trust in federations with ethnic territories and a secession clause challenges and opportunities for Ethiopia', 28 International Journal on Minority and Group Rights (2021), this issue.

10 C. Van der Beken, 'External and Internal Secession in Ethiopia's multinational federation', 28 International Journal on Minority and Group Rights, (2021), this issue.

$11 \quad$ L. Aalen., "The interplay between federalism and dominant party rule in Ethiopia and the Sidama's Quest for Statehood', 28 International Journal on Minority and Group Rights (2021), this issue. 